DOI: 10.53477/2668-2001-21-08

\title{
AL QAEDA AND HYPERTERRORISM - THE SUCCESSFUL EMERGENCE OF BINLADENISM AT GLOBAL LEVEL
}

\author{
Lucian Buciu ${ }^{1}$ \\ National University of Political Studies and Public Administration
}

\begin{abstract}
September 11, 2001 can be interpreted as a to (zero time) for the studies on terrorism, because that was the moment when the shift from classical terrorism to hyperterrorism occurred. The emergence of hyperterrorism at global level via Al Qaeda was successful owing to very well defined strategies and tactics, which were put into practice under Osama bin Laden's coordination. The indepth knowledge of the strategies and tactics of a complex enemy, who practices Islamic fundamentalist terrorism, constitutes a starting point in elaborating antiterrorist strategies adapted to the dynamism of the international security environment.
\end{abstract}

Keywords: hyperterrorism; Al Qaeda; strategy; tactic; Osama bin Laden.

\section{INTRODUCTION}

The September 11, 2001 terrorist attacks committed by AI Qaeda in the USA, targeting the World Trade Center and the Pentagon, marked a double global first: on the one hand, a world superpower such as the USA was attacked for the first time, not by a state, but a non-state actor and, on the other hand, classical terrorism was replaced by hyperterrorism.

As regards the progressive emergence of the concept of hyperterrorism, there were numerous analysts specializing in the issues of Islamic fundamentalist terrorism whose scientific approaches tended to label the September 11 events as new terrorism, unconventional terrorism or postmodern terrorism. This article considers the use of the concept of hyperterrorism to be more appropriate in terms of grasping the specificity of Al Qaeda's strategy, tactic and modus operandi, and studying the psychological profile of a "stateless and territoryless enemy" (Heisbourg 2003, 112) that practises a terrorism of Islamic fundamentalist origin, as are the perpetrators of the September 11, 2001 terrorist attacks.

\section{SEPTEMBER 11, 2001 AND THE SHIFT TO HYPERTERRORISM}

It should be stressed that the notion of hyperterrorism, as established in the studies on terrorism, is due to François Heisbourg, director of Fondation pour la Recherche Stratégique and president of the International Institute of Strategic Studies, recognized both in France and abroad as one of the leading experts in defence and international relations. His book, Hyperterrorisme: la nouvelle guerre, presents in a comprehensive and thorough manner both the theorization of hyperterrorism and the specificity of the Islamic fundamentalist terrorism practised by Al Qaeda at global level.

In this regard, nine eleven is a key moment, a to (zero time) for the studies on terrorism, since it makes the transition from classical terrorism to hyperterrorism in a rapidly globalizing world: "That day saw the shift from the logic of classical terrorism «Kill one, be seen by a thousand» to a new logic "Kill as many as possible and be seen by all.»" (Bourdillon 2007, 15)

Thus, hyperterrorism would be defined by „operations with a highly suicide and destabilizing potential, as opposed to "classical" terrorism, which only commits small-scale attacks, causing a few dozen victims.” (Bourdillon 2007, 10)

\footnotetext{
${ }^{1}$ Corresponding author: lucian.buciu@idr.ro
} 


\section{ON THE BASES OF THE FUTURE „BASE” (In Arabic, Al Qaeda means "base". Therefore, the term written with capital letter „Base" will be used with reference to Al Qaeda) - STAGES IN THE FORMATION OF AL QAEDA AND THE EMERGENCE OF BINLADENISM AT GLOBAL LEVEL}

The war in Afghanistan (1979-1989) provided a framework conducive to the emergence and consolidation of Binladenism. A first step was taken in 1979 by the Palestinian Abdullah Azzam, an important member of the Islamic fundamentalist group called Muslim Brotherhood, who laid the bases of the Afghan Service Bureau, also known as MAK - Maktab al-Khidamat. This bureau had as its main goal to recruit young Muslims animated by the desire to fight the invaders of Afghanistan. This is how Osama bin Laden was recruited and joined Abdullah Azzam, his professor of religion at the University of Djedda, in 1984. It should be stressed that Abdullah Azzam played a key role both in Osama bin Laden's spiritual moulding and in Al Qaeda: "Azzam, who is considered Osama bin Laden's spiritual master already asserts that the Islam will regain its purity only by engaging in the holy war against the infidels. [...] Azzam [...] is the genuine technical inspirator of the future Al Qaeda." (Rodier 2006, 31-33)

In a very short time, the new recruit Osama bin Laden got to understand the utility of the Islamic fundamentalist doctrine and to fully assume it, so that the future terrorist organization $\mathrm{Al}$ Qaeda became the symbol of Islamic fundamentalism: „For example, Al Qaeda, the terrorist group which became the flag ship of Islamic fundamentalism, promotes a Wahhabi ideology based on the identification of the "unbelievers" in the secular Western society, advocating the start of the "holy war" against the West, up to the supreme sacrifice and by any means." (Barna 2007, 39)

In 1980, Osama bin Laden set up the Islamic Salvation Front after previously declaring himself a supporter of the Pakistani Mujahedeens. In Saudi Arabia, he recruited Arab volunteers and was engaged in their instruction in training camps, to later make them join the war fought by the Afghan Mujahedeens. It should be emphasized that Osama bin Laden was involved in both the military training of the future fighters against the USSR and in the financial support which would play a key role for the future Al Qaeda. Bin Laden's recruitment strategy proved to be very efficient: in a very short time, he became a mentor, training about 10000 fighters, notably experts in undercover operations, sabotage and guerilla war, in his own camp of Peshawar (Pakistan).

If for Osama bin Laden, a first major role in his mobilization for fight was held by Abdullah Azzam, the Egyptian physician Ayman al-Zawahiri, a member of the group called the Egyptian Islamic Jihad, was to have a determining religious and political influence on Osama bin Laden: „Ayman alZawahiri was going to gradually impose his vision on the goals and principles of the Jihad: a "holy war", fought in the name of Allah, to release the Muslim-inhabited territories from all influence, of both the capitalist West and the comunist USSR." (Barna 2011, 25)

At this tactical level it is to be noted that the focus shifted from the war against the USSR to that against the capitalist West, an enemy which later turned out to be reduced to the USA. Or, in other words, bin Laden and Ayman al-Zawahiri had already decided that the future terrorist organization Al Qaeda, created in the 1990s, would globally impose binladenism, its own version of Islamic fundamentalism according to Osama bin Laden, which would promote an offensive Jihad: „An alliance between the Egyptian revolutionary jihadists and the defensive jihadists who had once fought in Afghanistan triggered the offensive jihad against the Western world, by creating Al Qaeda." (Raețchi 2019, 20)

In fact, Ayman al-Zawahiri became known as Osama bin Laden's right hand. At the same time, as author of „Knights under the Prophet's Banner”, the Egyptian Ayman al-Zawahiri has the main merit of having theorized the contemporary Jihad. The strategist al-Zawahiri manages to handle the Islamic fundamentalist discourse just like a linguist and to add a political dimension to the religious one, by legitimizing the use of suicide terrorist attacks on Western governments, institutions and even populations.

The war in Afghanistan came to an end after ten years of combat, by the victory of the Arab Mujahedeens against the USSR. Al-Zawahiri and Osama bin Laden wanted to mobilize so as to make 
Al Qaeda, „a group composed of former Afghan veterans of the holy war” (Barna 2011, 25) internationalize the Jihad against the US, Israel and the Muslim governments serving the West.

Osama bin Laden was forced by the Saudi dynasty to leave Saudi Arabia after requesting the Saudi government not to allow US military bases to be placed on the holy territory in the context of the Iraqi invasion in Kuwait. In 1991, Bin Laden settled in Sudan, where he strengthened his logistical basis for preparing the future terrorist attacks that were going to shake the international security environment.

In exile in Sudan, Osama bin Laden did not give up in any way his religious beliefs, according to which Islamic fundamentalism is the way forward for the Muslim world to free itself from the injustice to which it is subjected by the unfaithful West.

Therefore, bin Laden moved from words to actions and the inventory of the most important terrorist attacks committed by Al Qaeda at the order of its leader reveals an increasingly unprepared international security environment in the face of the threat of Islamic fundamentalist terrorism in the process of imposing itself at global level: 1993 - the attack on the World Trade Center; August 1996 the first fatwa issued by Osama bin Laden (,Declaration of War Against the Americans Occupying the Land of the Two Places", calling on the USA to initiate the procedure for the withdrawal of its soldiers from Saudi Arabia); February 1998 - religious decree issued by Al Qaeda (the obligation of every Muslim to kill Americans and their allies); 7 August 1998 - bombings of the United States embassies in Kenya (213 killed and 4500 injured) and Tanzania (11 people were killed after an explosive device detonated); October 2000 - the terrorist attack against the navy destroyer USS Cole as it was refuelling in the port of Aden (17 members of the crew were killed and 40 were injured).

Although the US intelligence services already had enough pieces of the puzzle designed by Osama bin Laden and AI Qaeda, they were, after all, unable to put the pieces of this puzzle together in order to realize what was going to follow - September 11, 2001 and the emergence of binladenism at global level. Even before September 11, $2001 \mathrm{CIA}$ concludes as clearly as possible that there was „no information on any specific plot in progress." (Raețchi 2019, 222). In fact, after September 11, 2001, the reform of the US intelligence community was going to be carried out as a matter of urgency.

\section{THE ISSUANCE OF RELIGIOUS DECREES (FATWA) BY STRATEGIST OSAMA BIN LADEN - A VERY WELL-DEFINED STRATEGY OF AL QAEDA}

For the Western democratic societies, which were used to the practice of issuing presidential decrees, the years 1996 and 1998 come with an element of novelty and propose another kind of decree - the religious decree, also known as fatwa. These are: the first fatwa issued by bin Laden in August 1996, known as the "Declaration of War Against the Americans Occupying the Land of the Two Holy Places" and the religious decree issued by Al Qaeda in February 1998, according to which every Muslim has the obligation to kill Americans and their allies, whether civilians or military. It is obvious that these two religious decrees issued by Al Qaeda emphasize once more that terrorism of Islamic fundamentalist origin poses a threat to international security.

At the same time, the two fatwas translate a very well organized strategy masterminded by Osama bin Laden, who managed to successfully mobilize members and followers of Al Qaeda starting from a discourse based on his personal religious interpretation of the Quran and Jihad, underlain by his own version. Bin Laden thus managed to join a radical religious dimension and a political dimension so that the two combine harmoniously and legitimize in front of the Muslims the conduct of the "holy war" against the infidels, with the aim of "returning to Islam" (Ferjani 2005, 17) in the face of westernization.

Although the Quran contains no reference to the encouragement of terrorism, Islamic fundamentalist terrorist groups justify their attacks as an expression of their obligation to fight the „holy war" in the name of Islam against the unfaithful West which threatens their culture and values and takes advantage of the natural resources of their land. One can note a significant difference, induced by the dimension with violent and armed tones which the Islamic fundamentalist terrorism promoted, from the meaning given by the Quran to Jihad as „each Muslim's inner struggle on the path to faith” 
(Barna 2007, 111): „It should be mentioned that, in the Quran, the term Jihad is not the equivalent of armed conflict, but it expresses each Muslim's inner struggle on the path to faith." (Barna 2007, 111)

The "merit" of strategist Osama bin Laden is that he successfully credited the religious dimension of Jihad with a strong political dimension, both of which combine harmoniously and legitimate the war against the West by the perpetration of terrorist attacks. The issuance of religious decrees (fatwa) by bin Laden may be interpreted as a legitimation of the holy war waged by the faithful against the unfaithful. Indeed, Osama bin Laden urges Al Qaeda members and suppoters to fight even at the price of the supreme sacrifice to impose the Islamic fundamentalist doctrine at global level. The success of a fatwa is highly dependent on the person who transposes it in words: "It should not be forgotten that the power of a fatwa entirely depends on the person who issues it." (Gunaratna 2002, 12)

It should also be emphasized that Osama bin Laden's effort of legitimizing "the holy war" against the unfaithful West is backed by the Egyptian physician Ayman al-Zawahiri, bin Laden's right hand, who, through his work "Knights under the Prophet's Banner", manages to highlight the political dimension of Jihad and to legitimize the combat against the West and modernity even more, going so far as to plead for the perpetration of suicide terrorist attacks: "The contemporary notion of Jihad has been reinvented, customized and turned into a political instrument." (Barna 2007, 23) Al-Zawahiri clearly distinguishes between the internal enemy, represented by corruption at government level, and the foreign enemy, represented by the US and Israel. Al-Zawahiri goes so far as to discredit UNO by calling it "Haiaa Kofria Almania Musaitira” ("Global Heathen Domination Organization”) in his efforts to criticize democracy, a "heathen religion" (Alexe 2019, 187) which is deeply incompatible with the values of Islam.

\section{TACTIC OF AL QAEDA}

The success of the near simultaneous bombings of the United States embassies in Kenys (213 people died and 4500 others were injured) and Tanzania (11 people were killed after an explosive device detonated) in 1998, of the terrorist attack against the navy destroyer USS Cole as it was refuelling in the port of Aden (17 members of the crew were killed and 40 were injured) in 2000, culminating with September 11, 2001, demonstrates that, in addition to a well developed strategy masterminded by strategist Osama bin Laden, Al Qaeda had an exceptional tactic that ensured the supremacy of binladenism.

An extremely important feature of Al Qaeda's tactics is represented, at structural level, by its octopus-like organization: "Al Qaeda is a genuine octopus, inflitrated in about seven other terrorist organizations, including Taliban, acting autonomously both internally and internationally." (Munteanu and Alexe 2002, 19) The octopus-like organization of Al Qaeda ensures the global spread of Islamic fundamentalist terrorism and it is the expression of a modus operandi that focuses on the simultaneous commission of terrorist attacks in different countries and, paradoxically, even on hitting targets situated on different continents. That is why the USA have often been unable to completely anihilate the AI Qaeda "superstructure" (Munteanu and Alexe 2002, 20)

Al Qaeda "superstructure" (Munteanu and Alexe 2002, 20) can also be interpreted from the perspective of the Phoenix bird symbolism in Greek mythology: even if an attempt is made to cut a tentacle, the other tentacles quickly mobilize and give concrete expression to the Islamic fundamentalist discourse by terrorist attacks committed simultaneously even in countries situated on different continents: "Another tactical feature is the obvious preference for multiple, even simultaneous attacks. In 1998, the US embassies in Tanzania and Kenya were bombed simultaneously. The September 11, 2001 attacks of the United States were also simultaneous."(Munteanu and Alexe 2002, 22)

The lengthy preparation of terrorist attacks is another strength of binladenist tactic, meant to maximize the success of the attacks committed and to work out all the details, so that Al Qaeda's plan should not be discovered and anihilated: "The bombings against the US embassies in Kenya and Tanzania had been prepared in five years (1993-1998) and the September 11, 2001 attacks in the USA took at least two years to be prepared." (Munteanu and Alexe 2002, 22) 
It has to be pointed out that Al Qaeda parent superstructure encompasses several terrorist organizations that develop rapidly through cells, so as to make the tentacle hits even stronger and impossible to anihilate, and get Al Qaeda to gain "worldwide coverage" (Munteanu and Alexe 2002, 20): Egyptian Islamic Jihad, Egyptian Islamic Group, Armed Islamic Group of Algeria (GIA), Turkistan Islamic Party, Islamic Movement of Uzbekistan, The Army of Muhammad of Kashmir and Abu Sayyaf Group of the Philippines.

"N.B.C. (nuclear, biological and chemical) superterrorism" (Munteanu and Alexe 2002, 21) is another particular feature of binladenist tactic as regards the commission of terrorist attacks. As compared with the so-called classical terrorism specific to the Cold War, materialized in seizures of embassies, hijacking of aircraft, car bombs, Osama bin Laden showed his tactical ingenuity by adding means of mass destruction to terrorism in the classical meaning. In 1998, the Arabic publication AlWatan al-Arabi brings to light evidence attesting that Osama bin Laden would have strengthened Al Qaeda's tactic by initiating a project to acquire Russian nuclear weapons.

Another specificity of the binladenist tactic resides in the communication method chosen so that the preparation and commission of terrorist attacks should not be discovered by governmental structures involved in preventing and combatting Islamic fundamentalist terrorism. From this point of view, "steganograms" represent the most secure channel of communication for Osama bin Laden and Al Qaeda: "Steganograms are encoded messages, hidden in other encoded messages on the web, or inserted into photos, films, music or radio programs. This steganogram-based communication makes it extremely difficult to monitor ben Laden's communications [...]." (Munteanu and Alexe 2002, 22)

Although strategy and tactics served him well for a long time and he eventually managed to hide in Pakistan for a decade, Osama bin Laden was killed in Pakistan, in the region of Abbottabad, on May 2, 2011 (at 1 p.m.) in an attack ordered by the American president Barack Obama as part of Operation Neptune Spear. The killing of Al Qaeda leader was officially confirmed through a press release of the Pakistani Foreign Affairs Ministry. Nevertheless, killing Osama bin Laden did not mean the total disappearance of hyperterrorism, just as the arrests of numerous Al Qaeda leaders did not lead to the annihilation of the "little Jihad, Jihad Al-achkar, the war against the other" (Marret 2005, 102), also known as "the holy war." (Marret 2005, 102)

\section{CONCLUSIONS}

In preventing and combating hyperterrorism and in developing counter-terrorism strategies adapted to the dynamism of the international security environment, a key element is the in-depth knowledge of the enemy. In the present situation, the enemy is a complex "stateless and territoryless" (Heisbourg 2003, 112) one, whose actions are harder and harder to predict. Therefore, the knowledge and thorough understanding of its strategies and tactics is a starting point in successfully preventing and combating Islamic fundamentalist terrorist attacks.

Besides "endurance and intelligence" (Heisbourg 2003, 226), a key role in combating Islamic fundamentalist terrorism is held by the intelligence services. Although the current trend in combating Islamic fundamentalist terrorism demonstrates the undeniable success of UAVs (Stamate 2019), HUMINT (all the information that can be obtained from human sources) (Sîrbu 2019) should in no case be neglected. On the contrary, it should be consolidated, considering that both human couriers and sleeper agents are two of the strengths that the hyperterrorism promoted by Al Qaeda masterfully refined.

\section{REFERENCES}

Alexe, Eva. 2019. Terorismul fundamentalist prin prisma relației dintre Islam și islamism. București: Editura Militară.

Barna, Cristian. 2007. Cruciada Islamului. București: Editura Top Form.

Barna, Cristian. 2011. Al-Qaida vs. restul lumii: după 10 ani. București: Editura Top Form. 
Bourdillon, Yves. 2007. Terrorisme de l'Apocalypse. Enquête sur les idéologies de destruction massive. Paris: Ellipses.

Ferjani, Mohamed-Chérif. 2005. Le politique et le religieux dans le champ islamique. Paris: Fayard.

Gunaratna, Rohan. 2002. Al-Qaida. Au cœur du premier réseau terroriste mondial. Paris: Éditions Autrement.

Heisbourg, François. 2003. Hyperterrorisme: la nouvelle guerre. Paris: Odile Jacob.

Marret, Jean-Luc. 2005. Les fabriques du jihad. Paris: Presses Universitaires de France.

Munteanu, Miruna and Alexe Vladimir. 2002. Misterele din 11 septembrie și noua ordine mondială. București: Editura Ziua.

Raețchi, Ovidiu. 2019. Avangarda Califatului: O istorie intelectuală a jihadismului. București: Editura Litera.

Rodier, Alain. 2006. Al-Qaida. Les connexions mondiales du terrorisme. Paris: Ellipses.

Sîrbu, Dana. 2019. „HUMINT. Intelligence din surse umane”. Accessed February 20, 2021. https://intelligence.sri.ro/humint-intelligence-din-surse-umane/

Stamate, Mihai Alin. 2019. „DRONE - O nouă eră a sistemelor de navigație aeriană fără pilot”. Accessed February 20, 2021. https://intelligence.sri.ro/drone-o-noua-era-sistemelor-denavigatie-aeriana-fara-pilot/ 